\title{
NOTAS SOBRE EL ACCESO A LA DOCUMENTACIÓN ADMINISTRATIVA (ACERCA DE LA PUBLICIDAD, LA TRANSPARENCIA Y EL SECRETO)
}

\author{
RAMIRO A. MENDOZA ZÚNIGA \\ Profesor Asistente de Derecho Administrativo \\ Facultad de Derecho - Universidad de Chile
}

\section{SUMARIO}

Introducción. I. Transparencia versus reserva. II. Las intenciones del constituyente: una claridad frustrada. III. ¿Cuál es el régimen vigente? IV. Conclusiones.

\section{INTRODUCCIÓN}

Irrumpen con fuerza en el ámbito comercial. Son logros destacados para cualquier gobierno, de la orientación que sea. Si antes se pregonó una suerte de internacional social, hoy la consigna es distinta. Se trata de ampliar los mercados, generando un desarrollo rápido de las potencialidades y ventajas que los países creen tener, confiados antes que en el esfuerzo posterior, en la magia de la suscripción. Ahí está el logro, llámese Maastrich, Acuerdo de Marrakesh, Ronda de Uruguay, Mercado Común del Sur, Nafta o Tratado de Libre Comercio de las Américas; algunos simplemente comerciales, otros anclando bases para integraciones de suyo más complejas, como si fueran estadios en un camino hacia un fin que se ignora.

Cualquiera sea nuestra afección o distancia, el hecho es que están aquí y no podemos ignorarlos, menos aún cuando en aquellos Acuerdos

*Abreviaturas usadas: DA Documentación Administrativa/Madrid; RD Revista de Derecho/Valparaíso; RDP Revista de Derecho Público/Santiago; REDA Revista Española de Derecho Administrativo/Madrid; REDC Revista Española de Derecho Constitucional/Madrid; RDJ Revista de Derecho y Jurisprudencia/Santiago; RTDP Rivista Trimestrale di Diritto Pubblico/Milano; RVAD Revista Vasca de Administración Pública/Oñate. 
de mayor complejidad, las exigencias que impone este orden de relaciones económicas entre los países, se insertan en bases fundamentales de la actividad administrativa que los países normalmente no evalúan hasta que deben cumplir los términos que pactaron.

Un ejemplo nos lo demuestra. El Tratado de Libre Comercio (NAFTA) contiene numerosas disposiciones relativas al tratamiento del tema de la confidencialidad de las informaciones que reciben las partes - sus Administraciones- en el marco de las actividades que puedan desarrollarse al amparo del Tratado, constituyendo diversas obligaciones para éstas y manteniendo como principio la nominada confidencialidad, fundamentalmente en el ámbito comercial a fin de no perjudicar las legítimas posiciones competitivas de las personas que las proporcionan ${ }^{1}$, sin perjuicio de que en otros ámbitos de sus disposiciones se encarga de consignar de que las Administraciones deben actuar con transparencia -priorizando para este efecto las Audiencias Públicas - y destacando que en lo relativo a su actividad de bien común, los ciudadanos tienen derecho, por lo menos, a exigirle los documentos que a ellos se refieran². Es decir, temas de nuestra disciplina se tornan de pronto relevantes y de necesaria urgencia, pues ya no se trata simplemente del reclamo de hacer carne el Estado de Derecho - que tan remolonamente asumió el legislador chileno desde $1925^{3}$ - , sino que de integrar prontamente las falencias que da cuenta nuestro ordenamiento, a través del control de la motivación de los actos (interdicción de la arbitrariedad), la plenitud de los controles (el principio de universalidad del control), la publicidad adecuada de la actuación administrativa, etc.

Ahora bien, este tema del acceso a la documentación administrativa, como se aprecia de la sola lectura de las disposiciones que se han advertido en nota, tiene aristas múltiples para su análisis, pues se refiere por una parte, a que las Administraciones y obviamente los funcionarios que las integran deben guardar reserva de aquellas materias que deben revertir tal

${ }^{1}$ Vid. art. 507.1.2; art. 1019.5.6; 1111.2; 1012.1, entre otras.

${ }^{2}$ Artículos 1802, 1804 del TLC, entre otros.

${ }^{3}$ En Chile, dada la consagración de lo contencioso-administrativo en el artículo 87 de la CP de 1925, y los términos en que la jurisprudencia acogió la tesis de la excepción de incompetencia por falta de jurisdicción que la Defensa Fiscal planteó con generosidad, es insostenible la creencia en un Estado de Derecho, el que en verdad comienza cuando los tribunales retoman la plenitud competencial sobre todos los actos de la Administración. 
tratamiento, por otra atiende a la circunstancia de que los sujetos - llámense inversionistas o ciudadanos-deben proporcionar a las Administraciones las informaciones que éstas le requieran para fines estadísticos o de información con el consecuente resguardo o secreto estadístico, y finalmente, la información no es un bien neutro, "por el contrario, puede jugar un papel fundamental en la estrategia de personas o grupos que, amparados en razones de solidaridad o de privilegiadas relaciones personales, pueden disponer de informaciones que se ocultan o no se permite su acceso a otras personas, dando así lugar a una práctica desigual en sus consecuencias partiendo de una invocación de la confidencialidad o secreto administrativo"4.

Es por ello, y a fin de evitar otras circunstancias, que se plantea actualmente, como premisa del correcto proceder de la Administración, la apertura informativa de ésta a los ciudadanos, estableciendo o consagrando un verdadero derecho a la información, que permite aumentar la protección de la Administración contra ella misma, contrarrestando de este modo sus prerrogativas, reforzando su control no sólo a través del voto, sino en la vida diaria por los ciudadanos, y en fin, haciéndola más servicial a la persona humana.

\section{TRANSPARENCIA VERSUS RESERVA}

Desde un tiempo a esta fecha - como advertíamos-, resulta del más alto interés advertir que lejos de mantener el velo del poder, las administraciones contemporáneas están siendo llevadas en torno a la transparencia de sus gestiones, que implica obviamente la publicidad de sus tramitaciones y de los correspondientes documentos que generan ${ }^{5}$. El secreto o "secretismo" de la administración, como una de las constantes de su actuación, hoy desaparecen,

${ }^{\dagger} J$.A. Domínguez Luis, El derecho de información administrativa: información documenlada y transparencia administrativa, en REDA 88 (1995) 537 ss.

${ }^{5}$ En este sentido, vid. especialmente Bermejo Vera, El secreto en las Administraciones Públicas. Principios básicos y regulaciones especificas del ordenamiento jurídico español, en REDA 57 (1988), 17; en igual posición Alvarez Rico, El derecho de acceso a los documentos administrativos, en DA 183 (1979) 104 ss.; con énfasis en el sentido histórico E. GómezReino y Carnota, El principio de publicidad de la acción del Estado y la técnica de los secretos oficiales, en REDA 8 (1976) 120; también J.M. Castells Arteche, El derecho de acceso a la documentación de la Administración pública, en Cuestiones finiseculares de las Administraciones Públicas, Civitas-IVAP. Madrid (1991) 181 ss. 
dificultosamente primero, pues forma parte de las reglas de oro que heredadas del Antiguo Régimen (junto a la "razón de Estado" entre otras) son verdaderos arcana regni, de suyo incompatibles con las exigencias que presenta una sociedad donde el hombre es el centro, fundamento y fin de los poderes con que se atribuye al Estado para servirlo. Esta sociedad precisa que la persona participe en los asuntos públicos y condición sine qua non, resulta ser su información, siendo relevante la accesibilidad, cantidad y calidad de aquélla.

Se trata en otras palabras, de abandonar el secreto como principio, el que sólo pudo justificarse en cuanto estaba ausente el derecho a la información y era la discreción la forma usual de actuación. Buscamos, ahora, organizar la transparencia de la actuación administrativa, no bastando la publicación o publicidad de la decisión administrativa terminal, pues con anterioridad a ella el ciudadano debe estar noticiado, advertido y facilitado, de esta decisión que viene, y para ello será necesario que se le permita acceder a los documentos de que tenga necesidad y a los que le sean útiles al ejercicio del derecho que se le va consagrando. No es un derecho a la decisión, en ella la administración podrá mantener los elementos de discrecionalidad que el legislador prevea, es un derecho a poder acceder a la información que es fuente de aquella decisión, y ojalá de manera previa a la irrupción de ésta en el ordenamiento. Por ello un autor ${ }^{6}$, ha señalado que la transparencia cualifica en los últimos años el movimiento de apertura de la Administración hacia el exterior y ha venido a suplantar el concepto de la publicidad de la acción administrativa que se había utilizado como término opuesto al de secreto administrativo, pero la idea de transparencia es más amplia y exigente que el de publicidad ${ }^{7}$, pues aquélla es política-sociológica, y ésta fundamentalmente jurídica.

Esta tendencia, mundial por cierto $^{8}$, se ha reflejado como una

11 ss.

GVid. Debbasch, en La transparence administrative en Europe. CNRS. Paris (1990)

${ }^{7}$ En materia de publicidad, como etapa fundamental del procedimiento administrativo, ver especialmente E.Soto Kloss, La preblicidad de los actos administrativos en el derecho chileno, en $\mathrm{RD} X$ (1986) 473-498; del mismo La publicidad de los actos administrativos en la jurisprudencia judicial, en RDJ, t.84 (1989) Doctrina, 23 a 27.

${ }^{8}$ Vid. en Francia la ley de 17.7.1978, que creó la Comisión de acceso a los documentos adminisirativos, modificada por ley de 1.7.1994 (que agrega un capítulo V bis, sobre datos referentes al sector salud); en Italia, la ley $241 / 7.8 .90$ "Sobre nuevas normas en materia de procedimiento administrativo y de derecho de acceso a los documentos administra- 
conducta asociada a la detención de la corrupción, como un aliciente de la eficiencia de sus actuaciones y fundamentalmente como una contribución a la participación de los ciudadanos en el procedimiento administrativo, quienes pueden en defensa de sus intereses allegar, previa vista de los antecedentes, las alegaciones y comprobantes que deben ser ponderados en la instrucción de los procedimientos.

Ello tiene un nombre disciplinariamente cual es el "Principio de transparencia de la Administración", o como consigna un Mensaje Presidencial de la "Transparencia de la función pública" y que no ha escapado de la preocupación actual de nuestros legisladores ${ }^{9}$ influidos ciertamente por el

tivos"; en Portugal, la Constitución de 2.4.1976; se considera de los primeros textos en reconocer este derecho expresamente. Así, su art. 35.1 recoge el derecho de todos los ciudadanos a "tomar conocimiento de lo que conste en forma de registros mecanográficos acerca de ellos y de la finalidad a que se destinan las informaciones y podrán exigir la rectificación de los datos así como su actualización", excluyéndose del derecho de acceso por parte de terceros aquellos documentos que contengan datos referentes a la intimidad de las personas (art. 37.2), debiendo en todo caso tenerse "interés legítimo y directo" y excluyéndose además de este acceso aquellos documentos que tengan relación con el ejercicio de la potestad disciplinaria o sancionadora (art. 37.3); en España, el art. 105.B de la Constitución expresa que "La ley regulará... B. El acceso de los ciudadanos a los archivos y registros administrativos, salvo en lo que afecte a la seguridad y defensa del Estado, la averiguación de los delitos y la intimidad de las personas", ley que se tradujo en la Ley Española de Procedimientos Administrativos de 1992 (Ley 30 de 26.11.1992), art. 37, que reguló el "Derecho de acceso a archivos y registros"; igual sentido asumen dos directivas de la Comunidad Europea, vid en particular DOCE $\mathrm{N}^{\text {o }}$ L158/56 de 23.6.1990, que consagra la Directiva del Consejo de 7.6.1990 sobre libertad de acceso a la información en materia de medio ambiente y la DOCE L135 de 30 de mayo que consagra la Directiva del Consejo de 21.5.1991 sobre Tratamiento de aguas residuales.

${ }^{9}$ Vid. en particular los Boletines legislativos que han sido el fruto del informe de la Comisión Nacional de Ética Pública y que contienen los №s. 1509/95, 1510/95 y $1511 / 95$, en especial éste y su Mensaje (12 de enero de 1995), donde establece "el principio rector del libre acceso a los documentos que se encuentren en poder de la Administración del Estado, permitiendo a toda persona obtener copia de ellos...". Otro antecedente de criterios puede consultarse en El Mercurio (Santiago) miércoles 21.6.1995, C 6; recientemente bajo el titular de Documentos secretos dificultan fiscalización, El Mercurio (Santiago) sábado 27.4.1996 C.8, volvía a la carga en el tema en análisis. Aludía la noticia fundamentalmente a que Parlamentarios de oposición estimaban que se hacía un uso y abuso de la imposición del secreto o reserva de los documentos 
derecho comparado ${ }^{10}$ y particularmente por la doctrina española surgida en el último tiempo, a la que tan receptiva nos hemos venido demostrandoll, cuya legislación fuera del ámbito de la información administrativa y en la consideración de la protección orgánica institucional del Estado para la intimidad de las personas a través de organismos administrativos (burocracia),

administrativos en perjuicio de la fiscalización parlamentaria; y más recientemente, en el mismo diario (29.5.1996 A-1 y A-11) donde bajo el sugestivo título de Escasa claridad en manejo de los papeles secretos, se pasaba revista al sistema chileno.

10 Vid. P. Barile Democrazia e segreto en Quaderni Costituzionali $\mathrm{N}^{\mathrm{N}} 1$ (1987), 29; L. Vandelli, L'acceso agli atti degli enti locali, en Regione e Governo Locale, $\mathrm{N}^{\mathrm{N}} 1$ (1988); v, recientemente, A. Scognamiglio, Il diritto di accesso nella disciplina della legge 7.8.1990. n.241 e il problema della legittimazione, en RTDP, №1 (1996), 93 a 114, con abundante bibliografía; para Francia: G. Debbasch, F. Moderne, J. Rivero, entre otros, en obra colectiva La transparence administrative en Europe, cit.; P. Dibout, Pour un droit à la communications des documents administratifs en Revue Administrative, $\mathrm{N}^{\prime 2} 173$ (1976), 493 ss; M. Herbiet, Le secret dans l'administration, en Annales de la Faculté de Droit de Liège, Nos. 1 y 2, 1975; J-M Auby y R. Ducos-Ader, Droit de l'information (10è. éd.) Dalloz. (1982) con bibliografia 187-198.

${ }^{11}$ Vid. entre otros El derecho de acceso a los archivos y registros administrativos. Algunas reflexiones en las visperas de su consagración legislativa de A.Embid Irujo, en "La protección jurídica del ciudadano" (Procedimiento administrativo y garantía jurisdiccional), Estudios en torno al Profesor Jesús González Pérez, 727 ss., t. I. Civitas (1993); de L.A.Pomed Sánchez, El derecho de acceso de los ciudadanos a los archivos y registros administrativos, Ed. Instituto de Administración Pública. Madrid (1989), 25 ss.; J.M.Castells Arteche, El derecho de acceso a documentación de la administración puiblica, en RVAP 10 (1984) 135 ss.; F.Sainz Moreno, Secreto e información en el desecho público, en 2863 ss. volumen III de "Estudios sobre la Constitución española. Homenaje al profesor Eduardo García de Enterría". Civitas. Madrid (1991); importante es también la sentencia del Tribunal Supremo Español de 16 de octubre de 1979, Ar. 3369, Pte. Femando Roldán Martínez, sobre ella en términos críticos vid F.Sainz Moreno, El acceso de los ciudadanos a los archivos y registros administratizos en REDA 24 (1980) 199 ss.; A.Sánchez Blanco, El sistema de archivos: de las referencias histórico-culturales a las bases de las administraciones públicas, en REDA, 67 (1990) 359 ss; E.Gómez Reino, El principio de publicidad de la acción del Estado y la técnica de los secretos oficiales, en REDA 8 (1976) 120 ss.; sobre abuso del "secretismo" interesante es T.R. Fernández Rodríguez, La organización territorial del Estado y la Administración Pública en la nueva Constitución, en Lecturas sobre la Constitución Española. UNED. Madrid (1978), 369 ss; A. Santamaría Pastor, Sobre derecho a la intimidad; secreto y otras cuestiones innombrables, REDC 15, 161 ss.; también es importante bibliográficamente J.A.Domínguez Luis, El derecho de información administratiza: información documentada y transparencia administrativa, 537 ss, en REDA 88 (1995). 
ha considerado la creación de una Agencia de Protección de Datos como da cuenta la ley orgánica 5 de 29 de octubre de 1992 acerca de la "Regulación del tratamien to automatizado de datos de carácter personal", y que da desarrollo a lo que la doctrina había señalado como el "derecho a la autodeterminación informativa" cuya raíz se encuentra en el artículo 18.4 de la Constitución Española.

En suma, para los efectos de nuestro interés, se trata de que la Administración - chilena por cierto- de acuerdo con la servicialidad que debe alentarle y en procura del encargo que le es encomendado como garante del Bien Común, sea transparente en su actividad.

\section{I AS INTENGIONES DEL CONSTITLYENTE: LNA CLARIDAD FRUSTRADA}

Nuestra Constitución ${ }^{12}$ obviamente no contempla el secreto administrativo, ni tampoco señala en disposición alguna el "derecho de acceso a la documentación administrativa", pero ello no es óbice a la existencia de tal derecho, no sólo por cuanto la Constitución no crea los derechos, sino que simplemente los reconoce y, como ella misma advierte, no lo hace íntegramente; sino que además, porque numerosas disposiciones de ésta reconocen o requieren un necesario acceso previo para el ejercicio del derecho público subjetivo consagrado, v.gr. el derecho constitucional de petición - art. 19 №14- o el derecho (libertad) a emitir opiniones y de informar, sin censura previa -art. 19 Nำ.

En torno a estos derechos, la Comisión de Estudios de la Nueva Constitución tuvo oportunidad de referirse al tema del acceso a las "fuentes", y en particular, a la cuestión de los límites de éstos frente al tema de la intimidad de las personas —art. 19 №4_, que la Constitución se encargó luego de garantizar con suma prolijidad, en atención a la fuerte influencia que sobre los comisionados ejercieron los constantes atropellos que en este ámbito produjeron las circunstancias del período 1970-1973 en nuestro país.

${ }^{12}$ Resulta si paradojal, que ya el comisionado Evans advirtiera que la comisión habia adoptado el acuerdo de no dar a conocer sus debates y mantener las actas en reserva, salvo para los Profesores de Derecho Constitucional; ver. Sesión 227, 30.6.1976, 14. 
El anteproyecto elaborado por la Comisión de Estudios de la Nueva Constitución no se extendió a las "fuentes de la información" o como en algún momento se expresó a las "fuentes accesibles a todos", luégo de significativas sesiones, donde primó un criterio orientado más a la noticia periodística que al derecho de las personas frente a la información de que dispone el Estado en relación a los intereses de los sujetos. En efecto, el texto del anteproyecto de la Comisión nada dice a este respecto, como lo demuestra el artículo 19 № 11, en el Capítulo de los Derechos y Deberes constitucionales, que expresó que la Constitución asegura a todas las personas "La libertad de emitir opinión y la de informar, sin censura previa, en cualquier forma y por cualquier medio, sin perjuicio de responder de los delitos y abusos que se cometan en el ejercicio de estas libertades, en conformidad a la ley. Con todo, los tribunales podrán prohibir la publicación o difusión de opiniones o informaciones que atenten contra la moral, el orden público, la seguridad nacional o la vida privada de las personas (inc. $1^{\circ}$ )", añadiendo seguidamente que "Asimismo, la Constitución asegura el derecho de recibir la información en forma veraz, oportuna y objetiva sobre el acontecer nacional e internacional, sin otras limitaciones que las expresadas en el inciso primero de este número" (inc. $\left.3^{\circ}\right)^{13}$.

Es a partir de la sesión 227 citada, cuando la Comisión aborda el tema de nuestro interés. En efecto, diversas intervenciones comienzan a dar cuenta del problema que luego se suscita, así consta en intervención de Jaime Guzmán (pág. 22) que señala: "Por una parte, se trata de un derecho de algunos de informar y de opinar, pero por otra parte, ha nacido el derecho de la comunidad a ser informada..."; la subcomisión ${ }^{14}$ encargada de esta materia, hablaba de que las fuentes de información sean "accesibles a todos"

${ }^{13} \mathrm{Su}$ texto puede consultarse en "Anteproyecto Constitucional y sus fundamentos", Comisión de Estudios de la Nueva Constitución Política de Chile, Editorial Jurídica de Chile, sin fecha.

${ }^{14} \mathrm{El}$ informe de la Subcomisión de Reforma Constitucional encargada de redactar el Estatuto Jurídico de los Medios de Comunicación Social y el derecho a informarse, consta como anexo en págs. 33 y siguientes de esta sesión. Ésta tuvo en particular consideración la Declaración de los Derechos del Hombre de 1948, art. 19 que señala: "Todo individuo tiene derecho a la libertad de opinión y de expresión lo que implica el derecho de no ser inquietado por sus opiniones y el de buscar, recibir y defender sin consideración de fronteras, las informaciones y las ideas por cualquier medio". 
(pág. cit), o "...el derecho de la comunidad y de cada persona a ser informado del acontecer nacional e internacional” (pág. 23). Son también interesantes los ejemplos en cuanto a destinatarios, las correspondientes administraciones son los destinatarios del ejercicio de este derecho, vale decir, este derecho tiene un obligado, sin otras limitaciones que las derivadas de la moral, el orden público, la seguridad nacional y la vida privada de las personas, salvo el interés nacional". "Respecto de las limitaciones —continúa Guzmán-, cree que se explican por sí solo aquellas derivadas de la moral, el orden público y la seguridad nacional, y lógicamente pueden restringir el derecho de la comunidad a ser informada sobre un problema o a recibir una noticia o un dato en un momento determinado"; “..., por lo cual es necesario que la vida privada quede como un límite al derecho a la información" (pág. 23), añadiendo, "... que piensa que no corresponde entregar a la ley la precisión de todo esto, porque, evidentemente, se trata de un tema que nunca podrá ser precisado en forma general, sino que habrá que ser resuelto casuisticamente por la autoridad, cuando de ella dependa, pero siempre quedará el recurso ante los Tribunales de Justicia, los que irán sentando jurisprudencia sobre qué se estima que es la seguridad nacional, el orden público, la moral o la vida privada de las personas, como limitación al derecho de informar". Agregaba enseguida que "Cree que debe nacer de la Constitución directamente a los Tribunales la facultad para que ellos se pronuncien sobre el particular y vayan precisando los contornos exactos de los mencionados conceptos, en relación con esta materia".

Por su parte, el informe de la subcomisión indicada consideraba que el derecho a informarse tiene tres aspectos fundamentales: a) el derecho a informarse individualmente como personas en la fuente, esto se traduce en acceder libremente a la fuente; b) el derecho a informarse como profesional para cumplir la misión de informar a través de medios de comunicación y, c) el derecho a informarse a la comunidad toda; y admitía que las limitaciones al derecho a informarse son: la seguridad nacional y el orden público, produciéndose luego disparidades de criterios en relación a la honra y a la privacidad de las personas, pues por una parte, Luz Bulnes señalaba que, además de las limitaciones aceptadas, esto es seguridad nacional y orden público, existe otro bien jurídico que es necesario proteger: el honor de la persona y su familia, "a menos que exista un interés público comprometido", ello por cuanto su atentado produce un daño irreparable; y por la otra, el miembro de esta subcomisión — señor Figueroa- sólo estaba de acuerdo en considerar como limitaciones a la seguridad nacional y el orden público. Usa también esta subcomisión un criterio: "que es la fuente accesible a todos". Surge entonces una pregunta: los documentos públicos, la información administra- 
tiva, aquella que maneja la administración zentran dentro del concepto de "fuentes accesibles a todos"? Señaló Figueroa (pág. 39) que "además, podrían cerrarse las puertas a toda investigación histónica o periodística que quisiera realizarse en el país...", se distinguió luego el acceso a la fuente y la emisión de la información. Schweitzer expresó - en su calidad de presidente de ésta- que "el derecho a informarse en las fuentes accesibles a todos debe sujetarse, subordinarse o someterse a tres limitantes: a) la seguridad nacional, b) el orden público, y c) el honor de las personas". Ello dio lugar a tres indicaciones (pág. 40): — de la señora Luz Bulnes “Asimismo, el derecho a informarse sin trabas en las fuentes accesibles a todos, con las limitantes relativas a la seguridad nacional, el orden público, y el honor de las personas, en las condiciones que establezca la ley"; - del señor Figueroa (que en definitiva aprobó la Subcomisión), "Asimismo, el derecho a informarse sin trabas en las fuentes accesibles a todos, con las limitaciones relativas a la seguridad nacional y al orden público que establezca la ley"; y, —del propio señor Schweitzer "Asimismo, el derecho a informarse sin trabas en las fuentes accesibles a todos, con las limitaciones que establezca la ley, relativas a la seguridad nacional, el orden público y el honor de las personas a menos que en esta última situación esté comprometido el interés nacional".

Éste fue el contexto inicial de la discusión.

Luego ${ }^{15}$, los comisionados se abocaron a ver las limitaciones con respecto tanto a la libertad de informar, como al derecho a ser informado, veraz, oportuna y objetivamente. Estaban contestes en que "el derecho de ser informado" era una novedad en el texto de una Constitución Política Chilena (págs. 6 y 7), lo que no evitó sucesivas confusiones en el tratamiento del derecho, como advierten sinceramente después de más de tres sesiones sin arribar a soluciones concretas, pese a que inicialmente Guzmán prácticamente visualizaba "el derecho a la información" como una entidad distinta al derecho a ser informado, lo que sí habría configurado una verdadera primicia constitucional. Expresaba (pág. 12) “Qué valor práctico tiene esta disposición, aparte de lo que entiende o trata de buscar en el sentido de su acierto teórico? Tiene el sentido práctico de que el Estado, las autoridades, en algunos momentos determinados, a través de normas juridicas no necesariamente de rango legal -y por eso también se opone a que se remita esto al Legislador, porque de lo contrario, si no se dicta la ley, se entenderá que todas estas limitaciones no regirán mientras la ley no sea dictada- pueden prohibir o disponer que determina-

${ }^{15}$ Sesión 231 de 8.7.1976. 
da información no debe darse ni trascender la luz pública como ocurre por ejemplo con todas las materias relativas a la seguridad nacional donde son los propios mandos militares o los Estados mayores los que le asignan a una materia determinada el carácter de reservada. Ahora bien, si esa disposición que señala que determinadas materias no deben llegar a la información pública se estima riolatoria del derecho de información y de la libertad de informar, quedarán los recursos ante los Tribunales. Por eso quiere (Guzmán) que esta norma descienda directamente de la Constitución a los Tribunales, para que éstos vayan juntando jurisprudencia en materias tan amplias y tan difíciles de precisar desde el punto de vista legal y preceptivo, como son todas éstas. Insiste en que entiende estas limitaciones como conceptualmente necesarias y para que descienda directamente a la jurisprudencia la facultad para ir precisando su contenido y alcance en materias como la vida privada, por ejemplo, respecto de la cual evidentemente es bastante dificil legislar. Debido a eso considera importante que la jurisprudencia vaya asentando qué es lo que se entiende por aspectos de la vida privada que comprometen el interés nacional y cuáles no; cree que no es necesario ni conveniente referir esto a la ley por las dos razones que ha señalado".

Así, paulatinamente, el asunto se fue haciendo cada vez más complejo, porque el derecho a la fuente en el fondo se mezcla con el derecho a dar después esa información, pensando los Comisionados, no en el uso del usuario, de la persona, sino que por los medios de comunicación social. En consecuencia, nunca se llega a una claridad desde el punto de vista del único agente o sujeto del derecho que se estaba consagrando, y podría añadirse que, para los comisionados fundamentalmente, estos sujetos eran los medios de comunicación social.

Quien nunca tuvo asomo de duda en torno a la importancia del acceso a la fuente y su relación con un derecho de acceso a la documentación administrativa fue Alejandro Silva. Como consta en actas - pág. 17"El señor Silva Bascuñán dice mirar las cosas en una forma más sencilla, cree que se ha incurrido en un exceso de sutileza innecesario, porque nuestro ordenamiento jurídico se las ha arreglado perfectamente bien sin este extremo sofisticado de disquisiciones. Siempre ha habido una legislación que ha permitido sujetar la obligación de informar respecto de situaciones en las cuales el constituyente o el Legislador han creído que esa obligación de informar no existía. Baste pensar sólo en dos situaciones muy concretas: que los derechos de informar y de opinar están implicados íntimamente en el mismo régimen. Lo que ocurre es que hay situaciones en que el constituyente o el Legislador consideran que no existe para la persona la obligación de 
informar. Y eso ha ocurrido no sólo en algunas normas expresas de la Constitución, sino también en muchas legislaciones, como por ejemplo, en materias de seguridad, de relaciones exteriores, de secreto profesional que las distintas profesiones han establecido en numerosas materias, justamente para que no rija en tales situaciones la obligación general de informar, en consecuencia, parece que la solución es de una sencillez enorme: que esa facultad que se ha reconocido siempre al legislador nacional, de establecer secretos ${ }^{16}$ —o sea, que no haya obligación de informar en las situaciones que él ha creído conveniente establecer-, quede amparada por una norma Constitucional. Por eso consignaría el derecho de informar y a ser informados, en la forma en que se propone, sin censura previa, sin limitación alguna, pero con la consiguiente responsabilidad, y añadiría que la ley determinará las situaciones en las cuales no existirá la obligación de informar por razones de orden público, de seguridad nacional, del honor y de la vida privada de las personas; así queda todo solucionado". En contrario, Díez, quien en la misma página señaló que prefería relegar el tratamiento del tema a circunstancias posteriores, no advirtiendo la relevancia inicial de la materia tratada. Igual situación acaece con Ovalle - pág. 22-, quien planteaba que "la libertad de informar consiste precisamente en que cada órgano, siendo veraz, informe lo que desee".

Con posterioridad, lejos de aclararse, la confusión siguió en su reino ${ }^{17}$. Guzmán planteó la importancia de seguir con el tratamiento del derecho a informarse sin trabas en las fuentes accesibles a todos (pág. 5), continuando -pág. 7- "el señor Guzmán prosigue diciendo que en segundo término, la consagración de ese derecho en esta forma se prestaría a graves inconvenientes prácticos, ya que no queda claro si se está refiriendo al hecho de que todo ciudadano puede ocurrir ante aquellos instrumentos que son públicos - lo que sería enteramente inútil establecer-, o si, en cambio, se está refiriendo al derecho del profesional de la noticia para recurrir a las fuentes accesibles a todos con el fin de obtener aquéllas"... "Fuentes accesibles a todos". Entiende que son todos aquellos órganos de la administración que

${ }^{16}$ Es decir, bajo este prisma -y con la autorizada doctrina del profesor Silva Bascuñán- es materia de ley el establecimiento de la reserva o secreto; circunstancia relevante en la búsqueda de un planteamiento general. Es que no puede permitirse, ni avalarse, que el burócrata de turno, sin razonabilidad que le apoye, pueda establecer, a su arbitrio, el sigilo en la gestión de lo público, ni bastarse para ello la supuesta fiscalización posterior que una determinada Cámara pudiere realizar.

${ }^{17}$ Sesión 232, de martes 13.7.1976. 
deben informar a los ciudadanos de lo que ocurre con la marcha del gobierno", reconociendo luego para este derecho un carácter social (pág. 27).

Se abocaron luego al problema de las limitaciones de este derecho a ser informado ${ }^{18}$. Su fuente de limitación fundamentalmente en la ley. Ortúzar agregaba: "establecer las limitaciones, referidas a la ley, en el derecho de ser informado, en los términos que lo ha propuesto el señor Guzmán, y luego, al tratarse de la libertad de informar, hacer una referencia, pero sólo a dos de ellas, que sería la seguridad nacional y la vida privada de las personas". Guzmán (pág. 8) "señala que la interpretación del señor Presidente es absolutamente exacta. Sólo desea agregar, para la historia de la disposición, que lo que quiere es que haya un texto Constitucional claro, que permita, frente a situaciones de hecho, que los Tribunales disciernan y digan efectivamente que no ha sido violado el derecho a ser informado porque a una persona determinada, particular, o a una generalidad de personas, no se le ha suministrado una cierta información, siempre que ello se haya hecho en conformidad a la ley y para preservar algunos de los valores que ha señalado". Luego, "el señor Ortúzar da lectura, a continuación, al texto del primer número del debate, y que es del siguiente tenor: el derecho a ser informado veraz, oportuna y objetivamente sobre el acontecer nacional e internacional, sin otras limitaciones que las que la ley establezca, derivadas a la moral, el orden público, la seguridad nacional y la vida privada de las personas, salvo que en este último caso se encuentre comprometido el interés nacional". Interviene entonces Silva Bascuñán (pág. 9) "señala que, en su opinión, el Legislador ya tiene una serie de casos en los cuales está perfectamente establecido el derecho de no informar: toda la esfera de lo que corresponda a la reserva y al secreto, que está en la Constitución y en las Leyes. De manera, entonces, que no hay problema alguno en cuanto a que vaya a quedar en descubierto toda racionalidad, por falta de encargo del legislador. Se trata, precisamente, de permitir a éste que en el futuro establezca, por norma expresa y dentro de los valores que constitucionalmente se consignaran, las reglas que podrían impedir la información. A su juicio, es muy importante que sea el legislador quien asuma esta tarea. Se sabe que, para negar en concreto un derecho, debe existir una determinación de la autoridad o persona que niegue la información, y ésa está basada en la ley. Ahora bien, ¿qué papel corresponderá a los Tribunales?: ellos examinaran la situación práctica, vale decir si las autori-

${ }^{18}$ Sesión 233, de 15.7.1976. 
dades basaron su negativa a la información en las normas que el ordenamiento jurídico consulta. Pero no es partidario de otorgar total libertad al legislador para establecer la negativa a la información, y estima que ella debe estar circunscrita nada más que a estos valores sustanciales". Intervención a la que se añade la postura de Guzmán (pág. 12), pues son ellos los únicos que advierten la necesaria consecuencia que la consagración de este derecho significará para el ciudadano común ${ }^{19}$. Insistiendo luego en el rol de los tribunales, dada la extensión de los términos fundantes de las limitaciones "... porque es cierto, como dice el señor Silva Bascuñán (continúa intervención de Guzmán, pág. 18) que la moral es muy amplia, pero lo es también la seguridad nacional, concepto de suyo amplio; no lo es menos el orden público, ni la vida privada de las personas. Entonces, se están estableciendo bienes jurídicos que son efectivamente muy amplios. ¿Dónde está la contrapartida?: en que no se entrega a nadie la facultad libérrima de entender estos bienes jurídicos a su arbitrio. Lo que en realidad se establece es la facultad de apreciar el problema, según el leal saber y entender de quien podría darle información. Pero, en definitiva, si hay controversia, serán los Tribunales los que con su jurisprudencia irán modelando el exacto sentido y alcance de estos bienes jurídicos como limitaciones al derecho a ser informado. Todos ellos; no solamente la moral. Y los Tribunales irán diciendo a cada instante qué se estima vida privada de las personas y qué no lo es, lo cual va cambiando con el tiempo. Y es bueno que la jurisprudencia lo tenga en sus manos para que ella evolucione de acuerdo a las circunstancias. Y va cambiando también la apreciación que se tenga sobre los otros conceptos que se consideran en este precepto".

No está demás insistir, que salvo atisbos de Guzmán y fundamentalmente de Silva Bascuñán, los constituyentes se avocaron fundamentalmente al derecho de la fuente como un elemento sustantivo que camina conjuntamente con el derecho a dar la información, en lo que inciden con frecuencia las intervenciones de Schweitzer y de Diez, agregando éste que (pág. 19) “..., desde luego, la ley 13.609 que obliga a contestar las consultas y a dar las informaciones que se solicitan por las Cámaras. Hay una autoridad administrativa la que perfectamente puede decir que esa información no la puede dar porque contraviene a la seguridad nacional. Es decir, para negar la información no se hará valer la autoridad administrativa, sino la seguridad

${ }^{19}$ Señala Guzmán "el hecho de poner limitaciones al ciudadano común" (pág.13), justificando la imposición de limitaciones al derecho de ser informado en el texto Constitucional, señalando los bienes jurídicos que se protegen. 
nacional ¿Qué sucedería si las oficinas de informaciones de algunas de las ramas del Congreso Nacional, por acuerdo de las cámaras pide una información al poder Ejecutivo relativa a una materia determinada? En el estado actual de la legislación pertinente, el Ejecutivo está obligado a darla. Y con la nueva disposición Constitucional éste no está obligado a hacerlo y puede contestar que no da la información porque está comprometida la seguridad nacional. ¿Qué puede hacer el Parlamento? Seguramente la nueva Constitución establecerá alguna forma de fiscalización o de juicio político (sic). Pero, se otorga a la autoridad el derecho a no dar la información, cuando estima que éste compromete algunos valores jurídicos". Dándose luego una polémica lógica entre Díez y Silva, así: "El señor Silva Bascuñán hace presente que a él le inquieta mucho el derecho de los ciudadanos. El señor Díez pregunta dónde están comprometidos aquí los derechos de los ciudadanos. El señor Silva Bascuñán expresa que los derechos de los ciudadanos pueden estar vinculados a tener o no tener una información que deba proporcionárseles. De manera, entonces, que los casos de excepciones en que la autoridad puede negarse deben estar establecidos, en su opinión, por el Legislador y decididos por la persona o autoridad correspondiente". Guzmán luego apuntaba que "No sea cosa, entonces, que la consagración del derecho, sin estipulación de las limitaciones en forma clara, pudiera inducir al intérprete a incurrir en equívocos" (pág. 19).

En la Sesión $234^{20}$, se sigue sobre la idea de los medios de comunicación social, pues es evidente que éste es el tema de preocupación fundamental. Ovalle asienta acá las líneas de su visión restrictiva en torno a la materia de nuestro interés, pero hace concesiones. Así en pág. 8, expresa “...que ése es otro problema, pero, ya que lo plantea el señor Guzmán, cree que el Estado tampoco puede ser obligado a dar otras informaciones que aquellas que dicen relación a su propia actividad, y los organismos del Estado tendrán que informar sobre aquello que sea susceptible de ser informado. Pero si no informan se podrá requerir la información, porque tampoco pueden desarrollar su gobierno en forma confidencial, lo que, en todo caso es un problema tangencial al asunto en debate". También señala —pág. 9que "por este motivo, cree que el debate está mal planteado desde sus inicios, porque el derecho a ser informado no es un derecho específico, sino que es la consecuencia natural de la existencia de esta libertad básica que es la de opinión, que conlleva una libertad que es distinta de ella, o que forma parte de ella como una especie del género, que es la libertad de información. Por

${ }^{20}$ De martes 20.7 .976 . 
eso, estima que el problema debe ser replanteado, y además, con respecto a la libertad de información, debe volverse, en su opinión, al inciso $2^{\circ}$....".

Evans -pág. 12_ “...hace notar que se está empleando mal la expresión, pues no se trata del derecho a ser informado, sino del derecho a recibir información"; "el señor Ovalle — pág. 13- estima que son expresiones del mismo problema, pues el derecho de informarse no existe, sino en función de la libertad de opinión y de información".

Como advertíamos, la claridad, en torno a nuestra postura la tiene fundamentalmente Silva B. -pág. 18- "el señor Silva Bascuñán deja testimonio de que durante varias sesiones han estado confundidos en este asunto, y cree que la discrepancia se debe en mucha parte a que no se ha podido entender claramente el problema, porque se trata, como lo ha recordado el señor Guzmán, de una novedad en la Constitución. Me parece que esta dificultad se debe a que se está haciendo un esfuerzo intelectual muy interesante, pero que choca con la naturaleza de las cosas, en el sentido de que en verdad no se puede separar como categoría intelectual distinta, sin perjuicio de las modalidades y matices, el derecho de informar, que forma parte de la libertad de opinión, con la obligación de informar, con el derecho de ser informado. En ese sentido hace presente que concurrió con mucho entusiasmo en la sesión última - y lo recuerda al señor Presidente- a dividir como categorías o números separados en el articulado estos dos derechos, y piensa que se está forzando lo que va en contra de la esencia de lo natural y material de la inteligencia. Estima que el derecho sustancial es fundamentalmente uno: el de opinar y de informar para todos, y cree que todas las demás modalidades que se están analizando aquí integran esencialmente ese derecho, porque dentro de ese derecho básico de informar y de opinar está la obligación del Estado de no perturbar la circulación de toda información y de la opinión que se produzca. Indica que dentro de este mismo derecho no está por cierto $-\mathrm{y}$ hay que reconocerlo claramente- la obligación de toda persona de informar cualquier cosa, pero si se encuentra la obligación del Estado de proporcionar la información que se le requiera, porque sería la uinica manera de ejercer el derecho de petición que se ha consagrado en favor de todos los ciudadanos y a la cual debe corresponder, naturalmente, la obligación del Estado de proporcionar la información que se le requiera". Agrega — pág. 18- "que estos planteamientos generales deben tener para ciertos valores y en relación a un encargo del legislador las excepciones consagradas, en las cuales el Estado no esté obligado a informar ni tampoco lo estén los particulares, porque no hay ninguna duda de que en esta obligación que tiene el Estado de no perturbar y de acceder a la información que se le pida hay casos excepcionales, en que el Estado no tiene esa 
obligación y tampoco la tienen los particulares, los que, si no son autoridad, jamás, en principio, están obligados a proporcionar información. Ciree que tampoco los particulares están en la necesidad de proporcionar información cuando hay valores que el legislador ha establecido que tienen que ser reservados. En consecuencia, le parece que debe reconocerse el derecho en general de informary de opinar; la obligación de lodos, especialmente del Eslado, de hacer circular la información; la obligación del Estado de proporcionar la información que se le requiem, salvo que el legislador, en ciertas situaciones, le permita negar esa información y, por altimo, la obligación que tienen los particulares de negar información cuando estén presentes también esos valores que el constituyente va a encargar al legislador que. determine, todo lo que, en su opinión, es el fondo del problema“.

Dícz hace una intervención que es reflejo de su pensamiento — pás. 21 _ "por último, estima que hay dos aspectos, que los vuelve a señalar, pues el señor Silva Bascuñán se refirió a ellos, y que dicen relación a que la obligación de informar del Estado es únicamente acerca de sus actividades propias, y tanto su obligación de informar como las limitaciones de esa obligación son atinentes a las funciones y atribuciones de los poderes públicos y al funcionamiento del sistema de separación de los poderes, y no cree conveniente relacionar la libertad de opinión y la de información con el derecho a ser informado, porque ésta es una información absolutamente específica enmarcada en los límites de acción del Estado. Piensa que ésta es la obligación que el Estado tiene de informar, que el Estado no tiene la obligación de informar sobre el acontecer mundial..."; continúa (pág. 22) "que hasta ese punto tiene las cosas claras, aunque puede ser posible que esté equivocado, pero cree que la obligación de informar del Estado es absolutamente específica y particularizada sólo a los actos del Estado; esa es la obligación de informar del Estado, y en consecuencia, debe ser tratada cuando se aborden los diversos órganos del Estado, sus funciones y atribuciones".

Es evidente que el alcance de Silva Bascuñán es mucho mayor, porque en realidad él visualiza dentro de este derecho de ser informado el real sentido que tiene para el ciudadano como derecho, el de acceder a la información que el Estado dispone en torno a los intereses de la persona y Díez las circunscribe en cierto ámbito de las funciones y atribuciones de los órganos del Estado y a ese respecto no le da el derecho de acceso que está planteando Silva Bascuñán, en relación al derecho que se está consagrando.

Hay con posterioridad ${ }^{21}$ una indicación de Silva B. - pág.

${ }^{21}$ Sesión 234, de 20.7.1976. 
24- "todo órgano público tiene obligación de informar veraz, oportuna y objetivamente en cuanto los asuntos de su respectiva competencia, sin otras limitaciones que las derivadas del orden público, la seguridad nacional y la vida privada de las personas en las situaciones que la ley contempla en resguardo de estos mismos valores; el legislador establecerá los casos en que los particulares estarán obligados a guardar reserva". También es importante tener presente que al final de esta sesión (234) hay una intervención de Díez que también es importante, pues al igual que la intervención de Silva B. da cuenta de las numerosas confusiones que tenía la comisión en torno al derecho de intimidad de las personas como limitante a la información: "el señor Díez (págs.31, 32) expresa que, a su juicio, están todos confundidos, pues se está hablando de la libertad de información, del derecho general a ser informado, y aunque tenga pésimos antecedentes (se refiere al nombramiento de una persona que no ha estado en cargos públicos) la comunidad entera no tiene derecho a ser informada al respecto; quienes designan al Contralor General - Presidente de la República y el Senado- y a esto quería llegar, tienen derecho a preguntar muchas cosas en el ejercicio de sus funciones, pero se están refiriendo a la información general, de la libertad de prensa y de la libertad de opinión, y no de la investigación para el desempeño y la provisión de cargos públicos, la cual, legítimamente, pueden llevar a cabo quienes designan a esas personas, ni tampoco se está hablando de actos que tengan relación con la función pública y que pueden ser investigados por el organismo fiscalizador correspondiente. Se están refiriendo - repite- al derecho a ser informado de toda la opinión pública, que es una cosa muy distinta". Esta última intervención es coherente con las opiniones vertidas por Silva B., pues en la generalidad del derecho a la información, éste percibía el deber de los órganos del Estado de informar, de poner los antecedentes que tuvieran a disposición para las personas que los requirieran, mientras que Díez este derecho nunca lo aparta de la asociación con la libertad de información.

La sesión $235^{22}$, no cesa el tratamiento de este tema, dando cuenta de complejas relaciones, originadas en una particular forma de presentar indicaciones, de modo colectivo, y rompiéndose el criterio tradicional, que estribaba fundamentalmente en la moción individual. Esta indicación - de originaria redacción de Ortúzar - es del tenor siguiente "La Constitución asegura: la libertad de emitir sus opiniones y la de informar sin censura previa

${ }^{22}$ De miércoles 21.7.1976. 
en cualquier forma y por cualquier medio, sin perjuicio de responder de los delitos y abusos que se cometan en el ejercicio de estas libertades en conformidad a la ley. Con todo, los Tribunales podrán prohibir la publicación o difusión de opiniones o informaciones que afecten a la moral, el orden público, la seguridad nacional o la vida privada de las personas. La ley podrá contemplar un sistema de censura para la cinematografia. Asimismo, la Constitución asegura el derecho a informarse sin trabas en las fuentes accesibles a todos y el de recibir la información en forma veraz, oportuna y objetiva sobre el acontecer nacional e internacional, sin otras limitaciones que las expresadas en el inciso primero de este artículo".

E. Evans - pág. 2- señala que en realidad él está de acuerdo con este precepto porque hay dos bienes jurídicos en juego, uno que sería personal que es el derecho de informar, el derecho de emitir opinión, de expresarse, y otro colectivo que es el derecho de recibir información, opiniones, expresiones que los demás quieran transmitir y éste sería colectivo porque sería un derecho que le correspondería a todos los integrantes de la comunidad nacional protegidos de que le lleguen sin censura previa. En realidad, lo que hay es un derecho personal, una libertad personal para emitir opiniones, y hay un derecho colectivo a recibir informaciones que en estricto rigor no es un derecho porque es la consecuencia del ejercicio de una libertad y entonces esa libertad encuentra como destinatarios a los demás miembros de la colectividad, sin perjuicio de las restricciones que le pueda imponer el Legislador a la misma; y hay otro derecho, que es un derecho de naturaleza individual y que dice relación con la información y el acceso a la información de las personas individualmente consideradas y fundamentalmente en relación a las informaciones que sobre las actividades, sobre los bienes y las personas mantiene el Estado y ése fue el sentido que tuvieron las intervenciones de Silva Bascuñán. Ello no se advirtió.

En cambio, la intervención de Silva B. - pág. 4- es sumamente lúcida "el señor Silva Bascuñán señala que le satisface esta proposición que a concurrido a firmar, por cuanto sortea esa verdadera prueba de inteligencia en que se encontraban tratando de separar totalmente y de manera conceptual dos aspectos íntimamente vinculados, los que lógicamente son más fáciles de considerar, incluso con sus matices, sobre la base de un mismo principio central. Le parece evidente que, como consecuencia de este texto, queda establecido que nadie, en general, tiene obligación de informar, y que será el Legislador quien, en ciertos casos, establezca la obligación de no informar ya a particulares, ya a órganos públicos, a fin de defender valores que deben permanecer en reserva o en secreto. Tal como ha ocurrido en el ordenamiento 
juridico actual, asi también prede ocurrir en el ordenamiento jurídico futuro: el legislador podrá establecer la obligación de no informar. Por otra parte estima que, si nadie tiene obligación de informar, los órganos públicos deben tenerla, por excepción, respecto de asuntos de su competencia cuando fueren requeridos, porque de otra manera no podría hacerse efectivo y siempre que tal información se encuentre en los casos que el Legislador haya establecido, a la inversa, la obligación de no informar.

Sobre esas dos bases, y sin perjuicio de complementarlas más adelante, como manifestó el señor Evans con otras disposiciones que ya son secuenciales y accesorias, han dado solución a la impasse en que se habían mantenido".

Sobre la crítica al concepto de "fuentes accesibles a todos" -en pág. 7- intervención de J.Guzmán "es posible que este concepto se entienda como aquellos documentos o fuentes de información que son públicos. Si ése fuere el sentido, es evidente que nadie podría oponerse a él, pero cree que es superfluo. En cambio, si por fuentes accesibles a todos se entienden los órganos que ejercen autoridad, le parece que puede dar lugar a dudas e inconvenientes muy serios en la aplicación práctica del concepto. Tampoco divisa la necesidad de consagrarlo. De manera que, hecha la salvedad anterior — por eso está remitiéndose solamente a este punto-, quiere sugerir que el inciso final se limite a decir "Asimismo, la Constitución asegura el derecho a recibir una información veraz, oportuna y objetiva sobre el acontecer nacional e internacional, sin otras limitaciones que las expresadas en el inciso primero de este artículo", eliminando del texto la referencia al derecho a informase sin trabas en las fuentes accesibles a todos, por las razones que ha señalado, que van desde lo superfluo, si se da un sentido como el que el propio señor Guzmán tiende a conferirle a la expresión, hasta lo inconveniente, si este sentido fuera el día de mañana confundido por los intérpretes y se pretendiera darle alcances que, cree, no puede ni debe tener este concepto, sobre todo erigido en un rango Constitucional sin referencia a ninguna definición o marco que permitan apreciar exactamente su sentido y alcance". Posición a la que Ovalle, se suma en págs. 10 y 11 , sin que Silva B., ceda en su planteamiento, así en otro contundente planteamiento expresa -pág. 12- "refiriéndose al punto concreto, queda mejor la referencia "a las fuentes accesibles a todos". Precisamente insistía en su aclaración de que, si no existe genéricamente la obligación de informar, sí se plantea a los órganos públicos en relación con su competencia, debido a que de otra manera, se hace imposible el ejercicio de la libertad de opinión. El Legislador, por lo tanto, tenía que quedar encargado de establecer aquellas situaciones en las 
que hay obligación de no informar, y "a contrario sensu" de lo anterior, respecto de todos los órganos públicos, viene el grado de esfera que les corresponde en la accesibilidad. Pero le gusta la frase, porque hay un encargo al legislador; en tanto, si la quitan, no existe más que la referencia de los Tribunales. Y le parece que además de la referencia a los Tribunales en la materia precedente, es preciso encargar al legislador que establezca las excepciones respecto de los casos en que existe la obligación de no informar. Porque si bien están de acuerdo en que no existe la obligación genérica de informar, que es excepcional para los órganos públicos, hay casos, tanto para los órganos públicos como para los privados, en que existe la obligación de no informar - en secreto profesional, la reserva en materia de seguridad, etc-, que puede afectar tanto a los particulares como al Estado. Por lo tanto, queda bien claro que no existe genéricamente la obligación de informar, pero que el legislador puede establecer obligaciones de no informar. Y por eso "las fuentes accesibles a todos" es una referencia al encargo al legislador y a la naturaleza de las cosas. De manera que prefiere que se mantenga esa frase, porque va a resultar, del juego de la legislación, cuál es la esfera en que rige la accesibilidad de todos a las fuentes de información respecto de los órganos públicos".

Añade Evans -pág. 14- que "la subcomisión utilizaba la expresión "fuentes accesibles a todos", con lo cual implícitamente reconoce que el Legislador puede señalar otras que no tendrán ese carácter" — o sea-, puede el legislador señalar fuentes que no sean o no estén, por su naturaleza, al alcance de todos. Preceptuando el derecho a la información sólo respecto de las primeras, es decir respecto de las fuentes accesibles a todos"... Es decir, son limitaciones al acceso a las "fuentes accesibles a todos": primero, la ley; y, segundo, toda resolución de los Tribunales fundada en los valores o bienes jurídicos que se preceptúan en el inciso primero. Por lo demás quiero recordar a la comisión que, concluido el debate general de este tema en la subcomisión, se presentaron tres indicaciones, de la señora Bulnes, del señor Figueroa y del señor Schweitzer, y que las tres emplearon la misma expresión "fuentes accesibles a todos". O sea la unanimidad de los Miembros de la Subcomisión estima que en una Constitución Moderna, el derecho de tener acceso a las fuentes de información es complemento del derecho a informar".

Pero luego Guzmán asume una postura significativa en contra de este concepto. Así - pág. 17- "El señor Guzmán expresa que, sobre el segundo punto, desea manifestar que sigue estimándolo innecesario y confuso, pues piensa si hay un derecho a informar, quien impide usar los medios 
para llegar a hacerlo está lesionando tal derecho. Le parece que ello fluye claro para cualquier Tribunal. Pero, a su juicio, "fuentes accesibles a todos" es una expresión extraordinariamente imprecisa y confusa", sin perjuicio de que la concepción de "órgano" a la que acude Guzmán, como fuente accesible, no tiene asidero alguno en la génesis del texto propuesto.

Es por ello que Silva B. - -pág. 19- expresó respecto... "de este mismo punto, el señor Guzmán señaló esta misma preocupación cuando trataron el derecho de petición. En definitiva, la norma se aprobó en los términos siguientes: "el derecho de presentar peticiones a la autoridad sobre cualquier asunto de interés público o privado sin otra limitación que la de proceder en términos respetuosos y convenientes. Es obligación de la autoridad dar respuesta a las peticiones que se le formulen, sin perjuicio de las restricciones que establezca la ley". "Las fuentes accesibles a todos" no configuran sino el encargo del legislador, ya aceptado por la Comisión en la norma recién leída, de determinar la esfera de las informaciones que la autoridad puede mantener en reserva. Se trata de fuentes determinadas por el legislador con aquel carácter y que resultan de esa frase de la Carta Fundamental y de la que habían aprobado. La majadería en cuanto a que el asiduo requerimientó de informaciones y de peticiones perturba el desarrollo de las funciones de la autoridad está prevista por el encargo al legislador para establecer preceptos que permitan a la autoridad defenderse de las reiteradas solicitudes de información sobre materias reservadas".

Donde comienza a quedar lisa y llanamente sepultada la novedad constitucional a que aludían en un principio los Comisionados, es cuando Evans continúa sobre la idea de que es una garantía no para todos sino que está dedicada expresamente "a los medios de comunicación social", para ellos son las "fuentes de donde emana la noticia", e insiste en la idea de que ésta no es una garantía que se otorga a todos los habitantes de la República, porque ello implicaría un poder de pedir cuentas a la autoridad (¿?). Agregaba - pág. 20- "lo único que pide es que tengan conciencia de que ésta, como ha sostenido muy bien el señor Guzmán, no es una garantía que pueda entenderse concedida o reconocida a todos los habitantes de la República, sino que es una garantía típicamente otorgada a los medios de comunicación social". Por ello es que Silva B. señala que no está de acuerdo con el señor Evans. "En todo momento había entendido que se trata de un derecho general de los ciudadanos la posibilidad de recurrir a las fuentes legalmente accesibles a todos, no sólo de los medios de comunicación social. Básicamente, existe una discrepancia: estima la norma en forma genérica, no sólo referida a los medios de comunicación social". 
Finalmente, es en la sesión $236^{23}$ donde pasan revista final al artículo pertinente. Ortúzar recordaba —pág. 4- que "había quedado pendiente para esta sesión lo relativo al derecho a informarse sin trabas en las "fuentes accesibles a todos". Surgirían dos posibilidades: eliminar lisa y llanamente este derecho, en el entendido de que está implícito en la libertad de emitir opiniones, o referirlo tal vez a los medios de comunicación social y al derecho a ocurrir a las fuentes de información en ultimo término, lo que no sabe hasta dónde podría ofrecer también dificultades". Guzmán, Ovalle y Diez estiman suprimirlo por estimarlo innecesario, tesis que no comparte Silva Bascuñán. Es más, agrega éste que (pág. 4) "no está de acuerdo en suprimirlo" "tan así no más", pero quizás sería partidario de cambiar las palabras "la Constitución asegura el derecho de informarse sin trabas en las fuentes accesibles a todos" por "en las fuentes de información que no tengan carácter de reservado". Le parece importante que exista un encargo al legislador para determinar la esfera o la órbita de lo que queda reservado por su propia naturaleza, porque, si no se coloca esa referencia, no quedaría nada más que la limitación inherente a la actuación directa de los Tribunales". Díez enseguida expresa "que es enemigo, como lo ha sostenido majaderamente en este debate, de incluir en la garantía individual la obligación del Estado de dar información acerca de los actos que le son propios. Cuando se estudie la organización del Estado, habrá que señalar, entre sus obligaciones a unos y sus atribuciones o facultades a otros, la obligación de dar información y el derecho de pedirla, lo que no tiene relación con la libertad de opinión" - y que en verdad hasta ahora no ha ocurrido-. Agrega que "Esto trae nada más que confusión y señala un derecho que no existe. Él no tiene derecho, como ciudadano, de ir a pedir cuentas al Ministro de Hacienda. En el funcionamiento normal de una democracia representativa está representado por un organismo fiscalizador que, actuando según determinadas normas, tiene derecho a pedir esa información. Aquí encuentra que hay una gran confusión de conceptos no se va a crear un sistema de democracia directa, sino uno de democracia representativa. De modo que son los organismos de esta última los que están obligados a informar o se encuentran facultados para pedir información, sin que ello tenga relación alguna con la libertad de información y la libertad de opinión. Cree - repite-, que aquí hay una confusión de materias"24. Enseguida, hubo réplica de Silva B.: "desea recordar nuevamente

${ }^{23}$ De jueves 22.7.1976.

${ }^{24}$ Este aserto es hoy de dudoso valor argumentativo. Expresa Chevalier y Loschak (Ciencia Administrativa, INAP. Madrid. 1986. tomo 1, 323) "la participación no 
lo que se analizó tanto en sesiones anteriores. Le parece evidente y está absolutamente de acuerdo en que para nadie existe la obligación de informar, salvo para los organismos públicos en las materias propias de su competencia para el efecto de hacer posible el derecho de petición. En eso - repite-, está absolutamente de acuerdo. Sin embargo, estima que la Constitución debe establecer la posibilidad de que el legislador determine en qué situaciones existe la obligación de no informar. Ese es el punto en que, entonces, Ie gustaría que quedara aclarado en la Carta Fundamental, porque en las primeras discusiones sobre la materia el señor Guzmán hizo valer ese vacío que existía en el texto actual, contestando una expresión de él que llevaba a sostener que, a pesar de ese vacío, el legislador se había "batido bien" - palabra que empleó-, pues, aunque no tenía ese encargo directo del constituyente respecto de cuándo existía la obligación de no informar, es decir, cuando una situación está amparada por el secreto, se había encargado en determinarlo. En consecuencia, quiere que haya un encargo explícito al legislador para precisar en qué casos existe la obligación de no informar, o sea, el secreto, por su naturaleza”.

Lo que luego no prosperó. Así Ortúzar (pág. 5), opina que es absolutamente innecesario, si no se va a establecer la obligación de informar, encargar al legislador determinar los casos en que ella no existe. Si esa obligación se consagrara, comprende la necesidad de señalar excepciones relativas a la reserva, pero ello no tiene objeto si no se va a hacer así, porque el legislador podrá disponer, como lo ha hecho hoy día, que, en ciertas situaciones debe guardarse el secreto profesional, de culto o de otra naturaleza”. Guzmán también coincide en ello.

Silva Bascuñan (pág. 10) "está muy interesado en que quede claro el derecho del legislador en dos sentidos. Primero, en el de establecer la obligación de informar por parte de la autoridad, en orden a su competencia, cuando sea requerida para el ejercicio de los derechos que la Constitución asegura a los demás habitantes. Ayer recordaba que esto es la consecuencia del derecho de petición. Si el derecho de petición existe, tiene que existir, para los órganos públicos, dentro de su competencia, la obligación de proporcionar las informa-

contradice la democracia; por el contrario, es susceptible de reforzarla instrumentalizándola mediante la ordenación de procedimientos diversificados de acceso de los administrados al aparato del Estado. La democracia de participación no tiene más que lejanas relaciones con el esquema clásico de la democracia representativa y formal, expresada por la papeleta del voto. Implica medios de acción y procedimientos concretos de intervención a disposición de los administrados". También, hace más de un siglo y medio, lo advertía $A$. de Tocqueville. 
ciones correspondientes. Esta es la primera pregunta que quiere hacer: está claro que el constituyente permite al legislador eso ¿sí o no?". A lo que Ortúzar replica "que tal como lo señalaba don Sergio Diez, está claro y quedará en claro también en otras disposiciones de la Constitución. Desde luego, en la que establece el derecho de petición que, naturalmente, implica la obligación correlativa de responder, como ya se dijo (lo que no ocurrió en el texto definitivo de la Constitución). Luego Silva B. agrega en pág. 10 que "segundo, a él le parece que también debe quedar en claro que el legislador estará facultado para establecer las situaciones en las cuales hay la obligación de no informar, o sea, aquellas en las cuales cabe la reserva o el secreto que, en algunos casos, rige respecto de particulares, y en otros respectos de la autoridad pública. Se le expresa por Díez "que no hay ninguna duda de ello. Y le parece muy bien que quede constancia”. A lo que Evans agrega “que, por lo demás, ésta ha sido la tradición jurídica en Chile desde que existen leyes de abusos de la publicidad y, especialmente, desde el año 1925 en adelante". También Díez recuerda a Silva B. que "la obligación de no informar existe y ha existido en la legislación desde siempre. Por ejemplo, en el Congreso en los reglamentos del Senado y de la Cámara de Diputados, que tienen valor de leyes de la República, está reglamentado todo lo referente al secreto: cómo se puede terminar el secreto, qué requisitos hay que tener para poder pedir antecedentes secretos, cuántos años después se acaba el secreto. Este secreto ha sido tan respetado, que aun, después de cerrado el Congreso, personas han pedido tener acceso a sesiones secretas y se les ha negado, porque no ha pasado el tiempo y porque no hay la autoridad - que es el Senado mismo- que pueda tomar el acuerdo correspondiente. Es el caso de los antecedentes que pidió el señor Exequiel González".

\section{III. ¿CUÁL ES EL RÉGIMEN VIGENTE?}

El sistema chileno actual de tratamiento de la información está fundamentalmente sustentado en:

1.

Ley 18.834 (Estatuto Administrativo) art. 55 letra h, que impone como obligación de cada funcionario "guardar secreto en los asuntos que revisten el carácter de reservados en virtud de la ley, del reglamento, de su naturaleza o por instrucciones especiales" que en esta parte fue bastante más generoso en la generación de medios de establecimientos de reserva que su 
precedente, el DFL 338/60 que consignaba sólo a la naturaleza y a la instrucción como habilitantes de tal reserva ${ }^{25}$;

2. El D.S. 291 (I) de 15 de febrero de $1974^{26}$ que consignó que los documentos u oficios se clasificarán en secretos, reservados y ordinarios; señalando que:

- los de carácter secreto serán conocidos sólo por las autoridades o personas a la cuales vayan dirigidos y por quienes deban intervenir en su estudio o resolución;

- los de carácter reservado serán los que traten de materias que, atendida su naturaleza, deben ser conocidos únicamente en el ámbito del departamento, sección $u$ oficina a que sean remitidos; y

- los de carácter ordinario serán aquellos que pueden ser de dominio público y abarcarán la correspondencia no comprendida en los caracteres anteriormente señalados.

Debe tenerse presente que el carácter de Reservado o Secreto consignado en su origen, como señala este Decreto Supremo, los mantiene excluidos del conocimiento público durante el plazo de 10 y 20 años respectivamente; y

3.

Numerosa jurisprudencia de Contraloría General de la República que en lo medular ha expresado que... "sobre el particular, es el caso manifestar que, según lo ha resuelto la jurisprudencia emitida por esta Contraloría General, contenida en los Dictámenes № s. 76.184, de 1974; y 26.087, de 1989, entre otros, los organismos de la Administración del Estado no están obligados a proporcionar información a particulares o suministrarles documentos o copias que les soliciten si esta información o tales instrumentos no les afectan directamente o no se vinculan con situaciones fácticas concretas en que les corresponda intervenir. Por otra parte, cabe hacer presente que la autoridad administrativa está impedida de proporcionar antecedentes acerca de asuntos que revistan el carácter de reservados en virtud de la ley, del reglamento, o que por su naturaleza presenten esa condición, tal como por lo demás lo previene el artículo 58 letra h) de la Ley $\mathrm{N}^{\mathrm{o}}$ 18.883, para el caso de los funcionarios municipales". (Dictamen 13.269/90).

${ }^{25}$ Vid. art. 155 DFL $338 / 60$.

${ }^{26}$ D.O. 26.04.74; Este D.S. fue modificado por DS (I) 1193 de 14.7.1994 (D.O. 8.09.94), y han sido dictados de conformidad al art. 14 del DFL 5200 (Educ) de 1929. 
Agrega también que "Sobre este punto, es dable añadir que la jurisprudencia de esta Contraloría General ha concluido que, salvo normas expresas que impongan a los organismos de la administración del Estado esos cometidos, no compete a éstos absolver consultas teóricas de los particulares o proporcionarles información con independencia de situaciones fácticas concretas que afecten a los peticionarios (Dictámenes № s. 26.087, de 1989; 13.269 , de 1990$)^{27}$.

En el mismo sentido, es útil recordar que el artículo 158 del DFL № 338, de 1960 -cuerpo legal abrogado por la Ley № 18.834 , que contiene el Estatuto Administrativo vigente y que no ha previsto una disposición análoga - regulaba la obligación del empleado que tuviere a su cargo la custodia de documentos, de permitir que el interesado en la tramitación de un expediente que le concierne tome conocimiento de "las piezas que vayan agregándose a dicho expediente y de las diligencias que se produzcan", esto

${ }^{27}$ En realidad, CGR desde antiguo ha validado una tesis restrictiva al respecto, ver al efecto el Dictamen № 76.184 de 18.10.1974, que expresa en lo pertinente: "Se ha solicitado a este Organismo Contralor un pronunciamiento acerca de la procedencia de otorgar a un particular copia de los Decretos o Resoluciones que emitan los Servicios Públicos. Al respecto, este Organismo cumple con manifestar que los Servicios Públicos sólo están obligados a proporcionar respecto de los particulares, copia de los decretos o resoluciones que emitan, en la medida que los actos que se materializan a través de dichos documentos, afecten directamente a la persona que los solicita. Por el contrario, si las medidas dispuestas por la Administración no alcanzan al peticionario, es facultativo para los Servicios Públicos proporcionar ese tipo de información, pudiendo por tanto, denegar la solicitud respectiva. Igual criterio restrictivo ha expresado recientemente en Dictamen № 19.089/96, cuando frente a un requerimiento hecho por el Instituto de Ecología Política para acceder a copia de un determinado proyecto de Reglamento Ambiental, el Ministro Secretario General de la Presidencia, en contradicción con la orientación pública en dicha materia contenida en oficio presidencial despachado por su misma cartera ministerial (Of. Seg. Pres (D.Ejec.) № 004 de 24.3.1994) que consignaba en lo pertinente: "transparencia, permitan que la gente vea lo que ustedes hacen. No nieguen el acceso a información o a la consulta de expedientes administrativos, a menos que la ley exija expresamente la reserva o secreto de los mismos (pág.5). Negado tal acceso por la vía de la inactividad (nunca hubo respuesta frente al requerimiento de la organización), Contraloría dijo simplemente, sin mayor consideración que "Por otra parte, es útil anotar que en la situación de que se trata, no existe ningün precepto legal —olvidándose que los órganos del Estado se someten no sólo a la ley, sino que a las "normas" que se dicten conforme a ella (art. $6^{0}$ de la Constitución)que obligue a la autoridad a proporcionar a los particulares copia del indicado reglamento en etapas anteriores a su total tramitación". 
es, de documentos determinados que afectan al requirente y con la salvedad de que "se tratare de materias reservadas por su naturaleza o a las que se hubiere dado tal carácter por la ley, los reglamentos o la orden escrita de autoridad competente". Añadió que "En concordancia con el criterio que fluve de lo expuesto, es oportuno considerar las instrucciones impartidas por esta Entidad Fiscalizadora mediante su Oficio Circular $N^{2}=51.336$, de 1971, con el fin de que los organismos de la Administración adopten medidas para otorgar la debida atención e información a los abogados que intervengan ante ellos en calidad de patrocinantes o mandatarios de un tercero en una determinada gestión administrativa". Concluyendo que "Por consiguiente, precisado que no es un imperativo legal para el Consejo de Defensa del Estado otorgar a los particulares un acceso general a sus archivos y teniendo en cuenta por otra parte, que la consulta se refiere a documentos que no revisten el carácter de secretos o reservados, de manera que tampoco existe un impedimento específico para darlos a conocer, esta Contraloría General cumple con informar que corresponde a esa misma autoridad administrativa ponderar y resolver si permite dicho examen, adoptando, en caso afirmativo, las medidas conducentes a la conservación de tales antecedentes" (Dictamen № 19.355/91).

Por su parte, el aludido Dictamen 51.336 de 28.7.1971, que contiene "Instrucciones relativas a la actuación de abogados como patrocinantes o mandatarios, en asuntos que se tramiten en servicios y entidades de la Administración del Estado", y que acoge explícitamente el principio de publicidad, ha dispuesto en lo que nos concierne que "..., es átil anotar que el ejercicio de la función puiblica impone al empleado, entre otros deberes primordiales, el de atender en forma cortés y esmerada a las personas que concurran ante él y, asimismo, obliga, en razón del principio de publicidad que rige, por regla general, respecto de las actuaciones de la Administración, a dar conocimiento al interesado o a su Abogado, acerca del estado de tramitación y de los antecedentes relativos a determinado asunto que concierna al mismo interesado. De acuerdo con lo expuesto, y en conformidad con lo prevenido en el artículo 68 de la ley 4409, procede que las distintas Reparticiones y Oficinas de los Servicios, Organismos, Instituciones, Empresas y demás entidades del Sector Público, adopten las medidas necesarias para que se dispen se la debida atención e información a los Abogados que intervengan ante ellas, en calidad de patrocinantes o mandatarios de un tercero, en determinada gestión administrativa. En tal virtud, corresponde que esas Reparticiones y Oficinas proporcionen a dichos profesionales, las informaciones sobre el estado de tramitación, antecedentes, documentación, diligencias y pronunciamientos relativos a tal clase de gestiones, y procede, igualmente, que acojan a tramitación y den el curso que corresponda a las presentaciones, solicitudes o mandatarios y, asimismo, que den a éstos las facilidades necesarias para que participen en las actuaciones administrativas que 
admiten la intervención del interesado o de su Abogado. En todo caso, es preciso tener en cuenta que lo anterior es sin perjuicio de aquellas situaciones que requieren la intervención personal del propio interesado, como también, de la obligación de reserva a que están afectos los servidores del Estado con respecto a las materias que por su naturaleza, for disposición legal o reglamentaria o por orden escrita de la autoridad. competente, tengan el carácler de secrelas o reservadas".

De todo lo expuesto se desprende que si bien nuestra CP no ha considerado expresa y formalmente la "Transparencia de la función pública", tal circunstancia no implica la consideración de un principio opuesto, ya que sólo esta transparencia es coherente con el principio de Servicialidad de la persona humana y el fin del Estado cual es el bien común 28 .

Porque además, no se vislumbra cómo el secreto o el sigilo de la actuación administrativa, sea coherente con la expresión de los principios de subsidiariedad, eficiencia, simplicidad, coordinación, oficialidad e impugnación, que entre otros impone a la Administración del Estado la Ley Orgánica Constitucional de Bases Generales del Estado ${ }^{29}$.

De allí - no obstante- que esta publicidad pueda también, en consecuencia, ser regulada en los términos y condiciones que ha prescrito la ley 18.834 y la abundante jurisprudencia contralora, a saber:

Por la $l e y^{30}$, por reglamento, por instrucción, por su naturaleza.

${ }^{24}$ Art. $1^{\circ}$ inc. $4^{\circ}$ de la C.P relacionado en el art. $3^{\circ}$ inc. $1^{\prime \prime}$ de Ley $18.5 \% 5$

${ }^{29}$ Vid., entre otros, arts. $5^{\circ}, 7^{\circ}, 8^{\circ}, 9^{\circ}$ y $10^{\circ}$ de la Ley 18.575 .

${ }^{30}$ V.g. secoto trilnulario (Código Tributario); secreto estadístico (ley. 17.374), entre otros. También la ley 10.336, 10.7.1964, Orgánica de Contraloría General, su art. $9^{\text {o }}$ El Contralor General estará facultado para dirigirse directamente a cualquier Jefe de Oficina o a cualquier funcionario o persona que tenga relaciones oficiales con la Contraloría o que le haya formulado alguna petición, a fin de solicitar datos e informaciones o de dar instrucciones relativas al servicio. El Contralor podrá solicitar de las distintas autoridades, jefaturas de servicio o funcionarios, los datos e informaciones que necesite para el mejor desempeño de sus labores, y podrá, también, dirigirse a cualquier autoridad o funcionario para impartir instrucciones relativas a la fiscalización que legalmente le corresponda. La falta de observancia oportuna de estos requerimientos podrá ser sancionada directamente por el Contralor General con la medida disciplinaria de multa de hasta 15 días de remuneraciones, sin perjuicio de que, si lo estima procedente, pueda disponerse la suspensión, sin goce de remuneraciones, del funcionario responsable de tal omisión, hasta que se le remitan los antecedentes o informes requeridos. Las normas que establezcan el secreto o reserva sobre determinados asuntos no obstarán a que se proporcionen a la Coniralona Ceneral la información o antecedente que ella requiera para 
el ejercicio de su fiscalización, sin perjuicio de que solve su personal pese igual obligación de guardar tal reserva o secreto. Art. 21: "La Contraloría hará el examen de inspección de los libros, registros y documentos relativos a la Contabilidad Fiscal, Municipal y de la Beneficencia Pública; efectuará la revisión de cuentas de todas las personas que administren fondos o bienes de los indicados en el inciso primero del art. $7^{\circ}$, y podrá exigir informes, declaraciones o datos a cualquier funcionario sujeto a la autoridad de su control". También el art. 131 que señala: "En uso de sus facultades, el Contralor General podrá constituir delegados en los servicios públicos y demás entidades sujetas a su fiscalización, con el fin de practicar las inspecciones e investigaciones que estime necesarias. Por este solo hecho quedarán bajo la autoridad del delegado el Jefe de Servicio y todo el personal, para los efectos de proporcionar los datos, informes, documentos y demás antecedentes que el delegado estime necesarios para la investigación". Art 135: "Los sumarios instruidos por la Contraloría serán secretos, el funcionario que dé información sobre ellos será sancionado hasta con la destitución". Art. 137 "No regirán para la sustanciación de estos sumarios plazos ni procedimientos especiales, aparte de las reglas generales que preceden, teniendo en cuenta que la rapidez, discreción e imparcialidad deberán ser los factores principales que los investigadores observarán al sustanciar sumarios administrativos". Art. 154 "La Contraloría velará por que se dé estricto cumplimiento a las disposiciones que prohíben la comunicación de los Decretos Supremos y resoluciones antes que de ellos haya tomado razón el Contralor. Para este efecto, los distintos Ministerios, al enviar al Diario Oficial o a otros órganos oficiales de publicación las transcripciones de los Decretos y de las resoluciones administrativas, deberán hacer estampar en ellas la constancia de que los respectivos Decretos y resoluciones han sido totalmente tramitados. En caso de incumplimiento de lo establecido en el inciso primero, se solicitará por la Contraloría la aplicación de las sanciones legales". También, Ley 19.366, Pub. D.O. 30.01.95 (Sanciona el tráfico ilícito de estupefacientes) señaló en su art. 15 "El Consejo de Defensa del Estado estará facultado para imponerse de cualquier sumario penal y de todo otro proceso reservado o secreto en que se sospeche fundadamente la existencia de antecedentes acerca de hechos constitutivos de los delitos contemplados en el artículo 12". En el art. 17 "La investigación administrativa que considera la presente ley, en forma previa a las gestiones judiciales es secreta, incluso bajo sanciones penales; es más, en los casos en que se haya requerido información en el marco de estos procedimientos administrativos -expresión que la ley utiliza -, la publicidad de tal requerimiento constituye delito para funciona nos, medio de comunicación, o incluso, particulares que hayan tomado conocimiento de este requerimiento. Por su parte el art. 18, señala que los archivos que no se utilicen por el CDE, cuando no ejercite las correspondientes acciones son secretos y quedan bajo la custodia del Secretario del Consejo. En el art. 33 inc. 8o "Todas las actuaciones judiciales y administrativas a que den lugar las medidas a que se refiere este artículo serán secretas. El empleado público que violare este sigilo será sancionado con la pena de presidio menor en sus grados medio a máximo". 
$Y$ todo ello, en cuanto tal regulación no afectare derechos garantizados por la Constitución o no mermare la esencia de los mismos ${ }^{31}$.

Parece necesario referirse también, en el ámbito de la ley, al Secreto Estadístico. De mucha menor complejidad resulta la obligatoriedad que importa la provisión al Estado - a la Administración- de las "informaciones rutinarias" para fines estadísticos, las que, al menos en Chile, tienen protección legal expresa en la ley de Instituto Nacional de Estadística, que al efecto incluso considera, para quienes lo violen, circunstancias típicas penales, es decir, comete delito quien materializa su quebrantamiento, sea agente del orden público o privado ${ }^{32}$.

\section{CONCLUSIONES}

Como anunciáramos al inicio, el desafio de esta integración que van produciendo los nuevos acuerdos internacionales de orden económico, está originando una necesaria revisión de nuestro derecho administrativo y un juzgamiento de su estado actual. Nos someten a un verdadero "test de blancura", que demuestre al menos, que no tenemos un subdesarrollo jurídico y que podremos ofrecer confianza a los nuevos sujetos de nuestro ámbito de relación. Y con certeza, podemos afirmar, que en general, nuestro ordenamiento es concordante con la vigencia de principios, que de pronto, se tornan universales. Es cierto, no hay ley que regule sistemáticamente, ni el procedimiento general de creación de actos administrativos y, menos habrá regula-

${ }^{31}$ Ver al efecto, art. 19 № 4 de la Constitución Política.

${ }^{32} \mathrm{El}$ artículo 29 de la ley 17.374, dispone al efecto que "El Instituto Nacional de Estadísticas, los organismos fiscales, semifiscales y Empresas del Estado, y cada uno de sus respectivos funcionarios, no podrán divulgar los hechos que se refieren a personas o entidades determinadas de que hayan tomado conocimiento en el desempeño de sus actividades. El estricto mantenimiento de estas reservas constituye el "secreto estadístico". Su infracción por cualquier persona sujeta a esta obligación, hará incurrir en el delito previsto y penado por el artículo 247 del Código Penal, debiendo en todo caso aplicarse pena corporal"; añade el artículo 30 de este mismo cuerpo legal que "Los datos estadísticos no podrán ser publicados o difundidos con referencia expresa a las entidades a quienes directa o indirectamente se refieran, ni mediare prohibición del o los afectados". 
ción con este mismo carácter de la reserva o secreto. Pero, en razón de lo expuesto, podemos, al menos asentar lo siguiente:

1.

En Chile, el principio que rige, como lo afirmó ciertamente la Comisión de Estudios de la Nueva Constitución, es el de publicidad del actuar de la Administración del Estado, única forma de hacer realidad el derecho de petición que la Constitución se encarga de consagrar. Máxime cuando se garantiza la intervención del letrado. Letra muerta sería que éste no pudiera siquiera acceder a la información que la Administración posee respecto de la persona que le ha encargado la defensa de sus derechos;

2.

Pero además, es la ley, como lo demuestra la discusión de la Comisión y los términos de los textos legales citados, la que debe encargarse de establecer el secreto o reserva de determinadas materias, y la autoridad administrativa podrá establecerlo, aunque digan los Reglamentos lo contrario, sólo en cuanto ha recibido el encargo del legislador para así disponer; y todo ello, en cuanto no se trate de reservas que se consideren en procedimientos que llevan a la imposición de sanciones, de cualquier naturaleza que sean, pues en esta circunstancia, este secreto o reserva siempre cederá en beneficio del posible sancionado, a fin de que se materialice el derecho a la defensa, elemento esencial en la estructura del debido proceso que la Constitución asegura siempre.

3.

La reserva o secreto por instrucción, esto es, por simple decisión administrativa, no tiene cabida. Pues dicha modalidad refleja un mero arbitrio o capricho, que el ordenamiento, a través de la interdicción de la arbitrariedad se encarga de execrar. No está a disposición del burócrata, sin soporte legal, decidir el sigilo para la actuación administrativa.

4 .

En todo caso, la Administración, por mandato expreso del artículo $6^{2}$ está sujeta directa y expresamente a la Constitución, y por ello, le corresponde a ella — y sus funcionarios- el deber de resguardar el ámbito de intimidad de aquellos terceros que le han proveído de datos e informaciones personales (de donde surge que existen los asuntos reservados por naturaleza), respecto de las cuales, los funcionarios están en el deber de mantenerlas dentro de la esfera de intimidad que corresponde, de modo tal, que si se vulnera este deber, aparte de las responsabilidades funcionarias que corresponden, el Estado está en el deber de reparar el daño que se ocasionare, por aplicación directa de los artículos $6^{\circ}$ y $7^{\circ}$, en sus correspondientes incisos terceros. 
5 .

En fin, no es inoficioso señalar que para la jurisprudencia judicial constituye una verdadera discriminación arbitraria, que conlleva a la indefensión, el hecho de que la Administración se asile en la reserva, para no dar respuesta a una pretensión del ciudadano ${ }^{33}$.

${ }^{33}$ Vid. Tironi Barrios con Presidente del Tribunal de Apelación de Calificación Cinematográfica, en RDJ, tomo 86 (1989), 5.2,191 ss. 